\title{
Enhancement of protein structure-forming properties in liquid foams by spray drying
}

\author{
Clémence BERNARD $^{1,2}$, Bertrand BROYART ${ }^{2}$ Jean VASSEUR $^{2}$, Pablo GRANDA ${ }^{1}$, \\ Perla RELKIN ${ }^{1 *}$ \\ ${ }^{1}$ UMR 1211 (AgroParisTech, CNAM, INRA), Laboratoire de Biophysique des Matériaux Alimentaires, \\ 1 Avenue des Olympiades, 91744 Massy, France \\ ${ }^{2}$ UMR 1145 (AgroParisTech, CEMAGREF, INRA), Laboratoire de Génie des Procédés, \\ 1 Avenue des Olympiades, 91744 Massy, France
}

\begin{abstract}
In the first part of this study we used mathematical modelling for prediction of hydrothermal pathways (time evolution of temperature and water content) of a whey protein-rich product during its spray drying in a co-current configuration. The model was validated through drying assays, where the inlet/outlet air temperatures were fixed at $170 / 85^{\circ} \mathrm{C}, 217 / 107{ }^{\circ} \mathrm{C}, 247 / 125^{\circ} \mathrm{C}$ or $260 / 138{ }^{\circ} \mathrm{C}$, the other spray-drying operation variables being unchanged. Then, the spray-dried powders were characterised before and after re-hydration for evaluation of a threshold air operating temperature value leading to changes in protein structure-functionality, in comparison with the nonspray-dried protein solution (WP-L). The predicted hydro-thermal pathways of the whey proteinrich product during its spray drying indicated that all of the operation variables used were accompanied by a product wet bulb temperature value lower than $60^{\circ} \mathrm{C}$. However, the resulting powders presented different internal porosity and wall thickness, and the protein solutions obtained after the powders' re-hydration behaved differently from the non-spray-dried protein solution (WP-L). Particularly, it seemed that powders obtained at outlet air temperature and water content higher than $100{ }^{\circ} \mathrm{C}$ and lower than $4 \%$, respectively, presented a higher internal porosity and lower free lactose content. Furthermore, they were accompanied by lower protein solubility and conformation stability and by a slight development of hydroxymethylfurfural and covalently-bound protein aggregates. In addition, in situ evaluation of foam formation and stability after air injection into the re-hydrated powders showed that increasing spray-drying air temperatures led to powders with more and more enhanced foaming properties, relative to the whey protein-rich solution before spray drying. The powder characteristics obtained in the present study, added to those recently published [Relkin et al., Lait 87 (2007) 337-348] are presented and discussed in regards to effects of spray-drying operation variables on protein structural changes and enhancement of foaming properties without additional processing equipment.
\end{abstract}

whey protein / spray drying / denaturation / aggregation / foam

摘要 - 喷雾干燥对蛋白质的功能性和发泡性的影响。本文前一部分研究了用数学
模型预测富含乳清蛋白的奶粉在顺流喷雾干燥器内的湿热变化途径 (温度和水分含
量与时间的关系)。在喷雾干燥工艺参数不变的情况下将干燥器内外空气温度分别固
定在 $170 / 85{ }^{\circ} \mathrm{C} 217 / 107{ }^{\circ} \mathrm{C} 247 / 125 .{ }^{\circ} \mathrm{C}$ 或 $260 / 138{ }^{\circ} \mathrm{C}$, 测定干燥过程的湿热变化, 经
验该模型与实际燥过程的湿热变化拟合的较好。此外, 还在能够导致蛋白质结
构和功能改变的极端空气温度下喷雾奶粉, 评价了该奶粉复水后的特性 $($ 原蛋
白质比较)。根据对富含乳清蛋白的乳粉在喷雾干燥过程中湿热途径的预测结果表明,

*Corresponding author (通讯作者): perla.relkin@agroparistech.fr 


\begin{abstract}
在湿球温度低于 $60^{\circ} \mathrm{C}$ 时伴随着其他工艺参数的改变。然而, 结果导致了终产品中出现了不 同的内部孔洞和较厚的孔壁, 乳粉复水后蛋白质的性质明显不同于未经喷雾干燥处理的蛋白 质。特别是在出口温度高于 $100{ }^{\circ} \mathrm{C}$ 和水分含量低于 $4 \%$ 时, 乳粉的内部孔洞率较高, 游离乳 糖的含量较低; 进而伴随着出现了蛋白质溶解性和构造稳定降低, 并出现少量的羧甲基糠醛 和以共价键结合的蛋白质凝聚物。将空气注入复水后的还原乳中, 原位评价了泡沫形成和泡 沫稳定性, 结果表明增加喷雾干燥空气的温度, 会使还原奶的发泡性大大改善。本文研究和 前期研究结果 (已在本刊发表, 2007) 证明, 在不改变生产工艺的前提下, 通过改变工艺参数 可以使乳蛋白质结构发生改变, 提高和改善产品发泡性能和泡沫稳定性。
\end{abstract}

乳清蛋白 / 喷雾干燥 / 变性 / 凝聚 / 发泡性

Résumé - Amélioration de propriétés moussantes de protéines par le séchage par atomisation. Dans une première partie nous avons établi un modèle mathématique décrivant l'évolution de la température et de la teneur en eau d'un produit riche en protéines sériques (WP-L) pendant son temps de séjour dans un séchoir par atomisation (configuration en co-courant). Après la réalisation d'essais à des températures d'entrée et sortie d'air fixées à $170 / 85^{\circ} \mathrm{C}, 217 / 107{ }^{\circ} \mathrm{C}, 247 / 125^{\circ} \mathrm{C}$ ou $260 / 138^{\circ} \mathrm{C}$ (les autres paramètres d'opération de séchage étant maintenus constants), nous avons caractérisé les poudres obtenues avant et après ré-hydratation. Nous avons observé que pour toutes les conditions opératoires testées, la température de thermomètre humide reste inférieure à $60^{\circ} \mathrm{C}$, pendant une durée diminuant de 10 à $5 \mathrm{~s}$ pour une température de sortie d'air (produit) variant de $85^{\circ} \mathrm{C}\left(59^{\circ} \mathrm{C}\right)$ à $138^{\circ} \mathrm{C}\left(134^{\circ} \mathrm{C}\right)$. Cependant, les poudres sortant à une température supérieure à $100{ }^{\circ} \mathrm{C}$ et un taux d'humidité inférieur à $4 \%$, semblent subir une montée en température beaucoup plus brutale après un palier à $60^{\circ} \mathrm{C}$ (température de thermomètre humide) d'une durée inférieure à $7 \mathrm{~s}$. Ces poudres présentent une porosité interne qui augmente $(\geqslant 40 \%)$ et une épaisseur de paroi (visualisée par microscopie électronique à balayage) qui semble diminuer avec l'intensité du traitement thermique. Les solutions protéiques obtenues après ré-hydratation des poudres présentent toutes des comportements différents de celui du produit liquide (WP-L) avant séchage. Particulièrement, les poudres sortant à une température $\geqslant 100^{\circ} \mathrm{C}$ contiennent moins de lactose libre et semblent présenter un début de développement d'hydroxy-methylfurfural, parallèlement à la diminution plus importante de la solubilité des protéines, de leur stabilité conformationnelle et à l'augmentation du développement d'agrégats protéiques covalents. De plus, la caractérisation in situ des propriétés de formation et de stabilité de mousses, obtenues par injection d'air dans les poudres ré-hydratées, a mis en évidence une amélioration croissante des propriétés moussantes des protéines sériques avec l'augmentation de la température d'air de séchage, comparativement au produit WP-L (concentré protéique avant séchage). La modélisation du comportement thermo-hydrique du produit riche en protéines sériques, lors d'un séchage par atomisation, accompagnée de l'évaluation de modifications structurales des poudres et de caractéristiques de stabilité conformationnelle des protéines en solution aqueuse, indique qu'il est possible d'améliorer les propriétés moussantes de protéines sériques, sans avoir recours à un équipement supplémentaire.

protéine du lactosérum / séchage / dénaturation / agrégation / moussage

\section{INTRODUCTION}

During spray drying, liquid droplets are atomised, evaporated and then transformed into a powder state under the effects of contact with hot air. Depending on the dryer design, drying parameters and product composition, liquid droplets can follow different hydro-thermal paths, during which their dissolved solids become increasingly saturated, form a solid crust on the droplet surface and finally lead to different spray-dried milk powder quality $[5,7,24,25,28,32,38]$. In numerous studies which focused on the quality of milk powders produced by spray drying, the authors considered the effects of processing parameters such as product flow rate in co- or counter-current configurations, atomisation speed and inlet air temperature $[1,3,5,7,24,32]$. Some authors have also considered the 
effects of heat-treatments applied before dryer feeding on protein aggregation or denaturation $[29,38]$. Most of the studies relating spray-drying parameters to quality of powders focused on characteristics such as density, average particle diameter, flowability or surface composition, but a few studies were performed on protein structural changes during their resident conditions (hydro-thermal pathway) inside the spray-dryer [1,3,34].

Analysis and prediction of the heat and mass transfer phenomena which occur during spray drying is a possible way to understand and control the effects of spraydrying operating conditions on the final powder quality. Recent studies showed that the computational fluid dynamics (CFD) approach can be used in spray-dryer design and by optimal setting of process parameters $[20,41]$. The CFD approach was used to predict flow patterns in spray-dryers [40] in relation to equipment wall deposition of particles [13].

Besides the CFD approach, numerous physical models based on mass transfer phenomena and drying kinetics have been developed $[4,21]$. These have considered the effects of liquid droplet size on drying kinetics of milk, including a validation step based on the effects of heating of liquid droplets. However, this model system, which consisted of liquid droplets with particle sizes appropriate for an experimental evaluation of mass loss, was found to be different from those produced by typical spray-dryer designs [12]. Other studies, which focused on the effects of spray drying, showed that water transfer, from bulk phase to the surface and from the surface to the drying air, differed depending on the environment of the water content and nature of the constituents [37], but without detection of product transformations due probably to air conditions (temperature, flow rate and water content) used for spray-drying simulation [8]; or experiments were conducted using re-hydrated dried powders, which were supposed to be in a native conformational state $[1,25]$.

It is well known that heat-treatments of globular protein solutions may be accompanied by protein conformational transitions from the folded native state to denatured states. Denatured proteins are characterised by less high-ordered structures, less initially buried amino-acid groups in the protein core, and a greater exposure to the solvent environment of hydrophobic and sulphydryl $(\mathrm{SH})$ groups than proteins in their initial structure [10, $14,27,33,35,36]$. On the other hand, it is well established that due to their amphiphilic (polar/non-polar) nature and marginal conformational stability, whey proteins may adsorb from aqueous solutions to solid surfaces and fluid/fluid interfaces and act as surfactants by reducing the interfacial tension and forming a cohesive film $[9,15,16,19,23,35]$. For some time, efforts have been made to develop standardised methods to differentiate between stable and unstable surfactantand/or protein-based foams [17, 30, 42]. Those methods are based on a combination of continuous measurements of foam volume (by an on-line video camera) and liquid (by conductivity) entrained during foam formation and drained during foam destabilisation. In addition, gas bubbles' video-images recorded simultaneously with conductimetric measurements of liquid drainage, after the end of gas sparging, may be analysed and used for evaluation of changes in the gas bubble size distribution during the destabilisation period $[17,18,42]$.

In the present study, we applied a simple mathematical model of the spray-drying process based on mass and energy balance between drying air and liquid droplets to predict hydro-thermal pathways of a whey protein-rich product when in contact with air at different operating temperatures. The predicted air and product temperature and water content will be compared 
with measured values, using recently published results [34] obtained from drying experiments performed at $170 / 85{ }^{\circ} \mathrm{C}$ and $260 / 138{ }^{\circ} \mathrm{C}$ inlet/outlet air temperatures, and using other results obtained at intermediate operating conditions $\left(217 / 107{ }^{\circ} \mathrm{C}\right.$ and $247 / 125^{\circ} \mathrm{C}$ ). The aim of the study will be to show how hydro-thermal transformations from liquid droplets into protein-rich particle powders could be related to operating air inlet/outlet temperatures on one hand, and on the other hand, to powder characteristics and to behaviour as a foaming food ingredient.

\section{MATERIALS AND METHODS}

\subsection{Physical modelling of product and air hydrothermal pathway in the dryer chamber}

\subsubsection{Main assumptions}

The model formulation is based on the following assumptions:

- The actual flow in the spray-drying chamber is approximated to co-current parallel plug flow for WPC droplets and drying air phases. At a given position, $z$, from the spray-dryer entrance, temperature, velocity and air humidity are assumed to be uniform over the entire section of the spray-dryer.

The droplets are assumed to have a spherical shape, uniform temperature and moisture content at a given position, $z$, from the dryer entrance.

- $v_{p}$, the liquid droplet velocity relative to $v_{a}$ (the drying air velocity) is assumed to be equal to a rigid sphere velocity (noted as $v_{l}$ ) in a fluid as described by Stokes' law $\left(\operatorname{Re}_{p}<1\right)$ :

$$
v_{p}=v_{a}+v_{l}=\frac{\dot{m}_{d a}}{\rho_{d a} A_{z}}+\frac{\left(\rho_{p}-\rho_{a}\right) g d_{p}^{2}}{18 \eta_{a}}
$$

where $v$ is the velocity $\left(\mathrm{m} \cdot \mathrm{s}^{-1}\right), \dot{m}_{d a}$ is the dry air flow rate $\left(\mathrm{kg} \cdot \mathrm{s}^{-1}\right), \rho$ is the density $\left(\mathrm{kg} \cdot \mathrm{m}^{-3}\right), A_{z}$ is the section of the dryer for a position $z, \eta$ is the dynamic viscosity $(\mathrm{Pa} \cdot \mathrm{s}), d_{p}$ is the particle diameter $(\mathrm{m}), g$ is the gravitational acceleration $\left(\mathrm{m} \cdot \mathrm{s}^{-2}\right)$ and subscripts $a, d a$ and $p$ refer to air, dry air and particle, respectively.

- The mechanism of particle shrinkage during drying was simplified $[11,31]$ and described in two stages: a first stage (shrinkage period), where evaporation of liquid leads to changes in the droplet volume, and a second stage, where a rigid crust is formed around the droplet which attains a critical moisture content $\left(n_{p c}\right)$ and a particle diameter close to the powder particles' median diameter $\left(d_{50}\right)$, as they exit from the dryer chamber. In the literature [21], the particle shrinkage effect under spray drying of a whey protein concentrate containing $30 \%$ dry matter was assumed to be accompanied by a $15 \%$ decrease in particle average size. Considering that the shrinkage of a liquid droplet under evaporation increases with decreasing dry matter content (Pierre Schuck, personal communication), we supposed that for whey protein samples containing $22 \%$ dry matter content, initial $d_{p}$ values are $20 \%$ higher than average diameter values evaluated from corresponding powders $[3,34]$.

\subsubsection{Exchange area between air and particle $\left(S_{a p}\right)$}

Further calculations need knowledge of the number of particles at a given position, $z$, from the dryer entrance. $N_{p}$ (in number of particles/m of dryer) is calculated as:

$$
N_{p}=\left(\dot{q}_{d p}\right)_{i} \cdot \frac{1}{V_{p i}} \cdot \frac{1}{v_{p}}
$$


where $\left(\dot{q}_{d p}\right)_{i}$ is the inlet product flow rate (on a dry matter basis) at the position $z=0$ $\left(\mathrm{m}^{3} \cdot \mathrm{s}^{-1}\right)$ and $V_{p i}$ is the initial average particle volume $\left(\mathrm{m}^{3}\right)$.

The exchange area $\left(S_{a p}\right)$ between air and particle is then calculated from:

$$
S_{a p}=S_{p} \cdot N_{p},
$$

where $S_{p}$ stands for the apparent particle surface $\left(\mathrm{m}^{2}\right)$.

\subsubsection{Estimation of external heat and mass transfer coefficients}

Nusselt (Nu), Reynolds ( $\mathrm{Re})$ and Prantl (Pr) numbers are used in the estimation of the external convective heat transfer coefficient, $h\left(\mathrm{~W} \cdot \mathrm{m}^{-2} \cdot \mathrm{K}^{-1}\right)$ :

$$
\operatorname{Re}=\frac{\rho_{a} v_{l} d_{p}}{\eta_{a}}
$$

and

$$
\begin{gathered}
\operatorname{Pr}=\frac{C p_{a} \eta_{a}}{\lambda_{a}} \\
\mathrm{Nu}=\frac{h d_{p}}{\lambda_{a}}=\beta_{\mathrm{Nu}} \operatorname{Re}^{0.5} \operatorname{Pr}^{0.33}
\end{gathered}
$$

where $C p$ is the specific heat $\left(\mathrm{J} \cdot \mathrm{kg}^{-1} \cdot \mathrm{K}^{-1}\right)$, $\lambda_{a}$ is the thermal conductivity $\left(\mathrm{W} \cdot \mathrm{m}^{-1} \cdot \mathrm{K}^{-1}\right.$ ) and $\beta_{\mathrm{Nu}}$ will be identified by comparing simulated and measured drying outlet parameters. The external mass transfer coefficient, $k\left(\mathrm{~kg} \cdot \mathrm{m}^{-2} \cdot \mathrm{s}^{-1} \cdot \mathrm{Pa}^{-1}\right)$, is related to the external convective heat transfer coefficient, $h$, using the Loncin and Bimbenet equation [22]:

$$
k=\frac{h}{65 \Delta H_{v a p, T_{p}}}
$$

where $\Delta H_{v a p, T p}$ is the latent heat of vaporisation at the product temperature $\left(\mathrm{J} \cdot \mathrm{kg}^{-1}\right)$.

\subsubsection{Constitutive balance equations of the model}

Constitutive energy and mass-transfer balance equations used in this study are summarised in Table I, where $\dot{m}$ is the mass flow rate for dry product $\left(d_{p}\right)$ and dry air $\left(d_{a}\right)\left(\mathrm{kg} \cdot \mathrm{s}^{-1}\right), n$ is the moisture content $\left(\mathrm{kg} \cdot \mathrm{kg}^{-1}\right), p_{v s a t, T p}$ and $p_{v a}$ are, respectively, the saturated vapour pressure at the product temperature and the vapour pressure $(\mathrm{Pa})$, $T$ is the temperature $(\mathrm{K}), U$ is the global transfer coefficient $\left(\mathrm{W} \cdot \mathrm{m}^{-2} \cdot \mathrm{K}^{-1}\right), r_{t}$ is the dryer radius (m) and subscripts $a, p$ and $w$ refer to air, particle and water, respectively.

In this model, the droplet drying kinetics are expressed by using the Oswintype equation [2] where $\psi^{*}\left(p_{v s a t, T_{p}}\right)$ is used to relate droplet vapour pressure depending on the average moisture content $\left(n_{p}\right)$ and temperature $\left(T_{p}\right)$ :

$$
\psi=\frac{\left(\frac{n_{p}}{k_{0}+k_{1} T_{p}}\right)^{k_{2}+k_{3} T_{p}}}{1+\left(\frac{n_{p}}{k_{0}+k_{1} T_{p}}\right)^{k_{2}+k_{3} T_{p}}} .
$$

In this equation, $k_{0}, k_{1}, k_{2}$ and $k_{3}$ are empirical parameters which have to be identified, using experimental trials characterised by different air inlet and outlet temperatures.

\subsection{Experimental}

Spray drying of a whey product ( $\mathrm{pH}$ 6.7) prepared by ultrafiltration of skimmed milk (Ingredia-Arras, France) was performed in a pilot-scale dryer (Niro Minor pilot, GEA, Niro Atomiser, Bochum, Germany), with an atomiser rotary disc type, and feeding in drying air in a co-current configuration, as described previously $[3,34]$. In the present study, we report results obtained by spray drying at four air inlet temperatures (170, 217,247 and $260{ }^{\circ} \mathrm{C}$ ), the other operational variables such as the product and air flow 
Table I. Constitutive energy and mass-transfer balance equations used in this study.

\begin{tabular}{ll}
\hline Description & Equation \\
\hline Mass balance for a single particle & $\dot{m}_{d p} \mathrm{~d} n_{p}=-k_{p} S_{a p}\left(\psi p_{v s a t, T_{p}}-p_{v a}\right) \mathrm{d} z$ \\
Energy balance for a single particle & $\dot{m}_{d p}\left(C p_{d p}+n_{p} C p_{w}\right)\left(\frac{\mathrm{d} T_{p}}{\mathrm{~d} z}\right)=h S_{a p}\left(T_{a}-T_{p}\right)+\ldots$ \\
& $\ldots \dot{m}_{d p}\left(\frac{\mathrm{d} n_{p}}{\mathrm{~d} z}\right) \Delta H_{v a p, T_{p}}$ \\
Mass balance for gas phase & $\dot{m}_{d a} \mathrm{~d} n_{a}=k S_{a p}\left(\psi p_{v s a t}-p_{v a}\right) \mathrm{d} z$ \\
Energy balance for gas phase & $\dot{m}_{d a}\left(C p_{d a}+n_{a} C p_{v a p}\right)\left(\frac{\mathrm{d} T_{a}}{\mathrm{~d} z}\right)=h S_{a p}\left(T_{p}-T_{a}\right)+\ldots$ \\
& $\ldots \dot{m}_{d a}\left(\frac{\mathrm{d} n_{a}}{\mathrm{~d} z}\right) C p_{v a p}\left(T_{p}-T_{a}\right)+2 \pi r_{t} U\left(T_{\infty}-T_{a}\right)$ \\
\hline
\end{tabular}

rates being unchanged (around $3.4 \mathrm{~kg} \cdot \mathrm{h}^{-1}$ and $104.4 \mathrm{~kg} \cdot \mathrm{h}^{-1}$, respectively).

The different powders were characterised through their particle median diameter $\left(d_{50}\right)$ and density $\left(\rho_{p}\right)$ values, as described in a previous paper [34]. The volume particle size repartition was determined by using light-scattering equipment (Malvern Mastersizer - MS 1000 - Malvern Instruments, Orsay, France). The internal porosity (percentage of non-accessible pores to air) was evaluated using a parameter $(\varepsilon)$ deduced from $\rho_{p}$ and $\rho_{p g}$, the powder particle density before and after grinding:

$$
\varepsilon=\frac{\rho_{p g}-\rho_{p}}{\rho_{p g}} \times 100 .
$$

Internal porosity values were also evaluated using scanning electron microscopy images obtained from observations of the particle size and wall thickness from powder samples, before and after grinding [34].

The whey protein-rich products were characterised before and after drying using methods previously described [3,34] for determination of dry matter, ash, protein and lactose contents, protein solubility and composition in terms of whey protein monomers and covalently-bound aggregates, and protein conformation stability under effects of heat-treatments.
Particularly, liquid and re-hydrated dried protein-rich powders were characterised using SDS polyacrylamide gel electrophoresis [39] in dissociative conditions (SDS-PAGE) for their changes in protein composition in terms of monomer and high-molecular-weight covalently-bound aggregates; for their changes in free lactose and hydroxymethylfurfural (HMF) content, and for their changes in protein conformational stability [33] using differential scanning calorimetry (Perkin Elmer DSC VII, Courtabœuf, France).

\section{RESULTS AND DISCUSSION}

\subsection{Powder characteristics}

The protein-rich product was spray dried in a co-current configuration using four different values of air inlet temperatures, while the other processing parameters, such as the product flow rate and the air flow rate, were unchanged $\left(3.4 \mathrm{~kg} \cdot \mathrm{h}^{-1}\right.$ and $104.4 \mathrm{~kg} \cdot \mathrm{h}^{-1}$, respectively).

Predicted and measured characteristics of air and product exiting from the dryer chamber are reported in Table II, and product hydrothermal pathways obtained using 


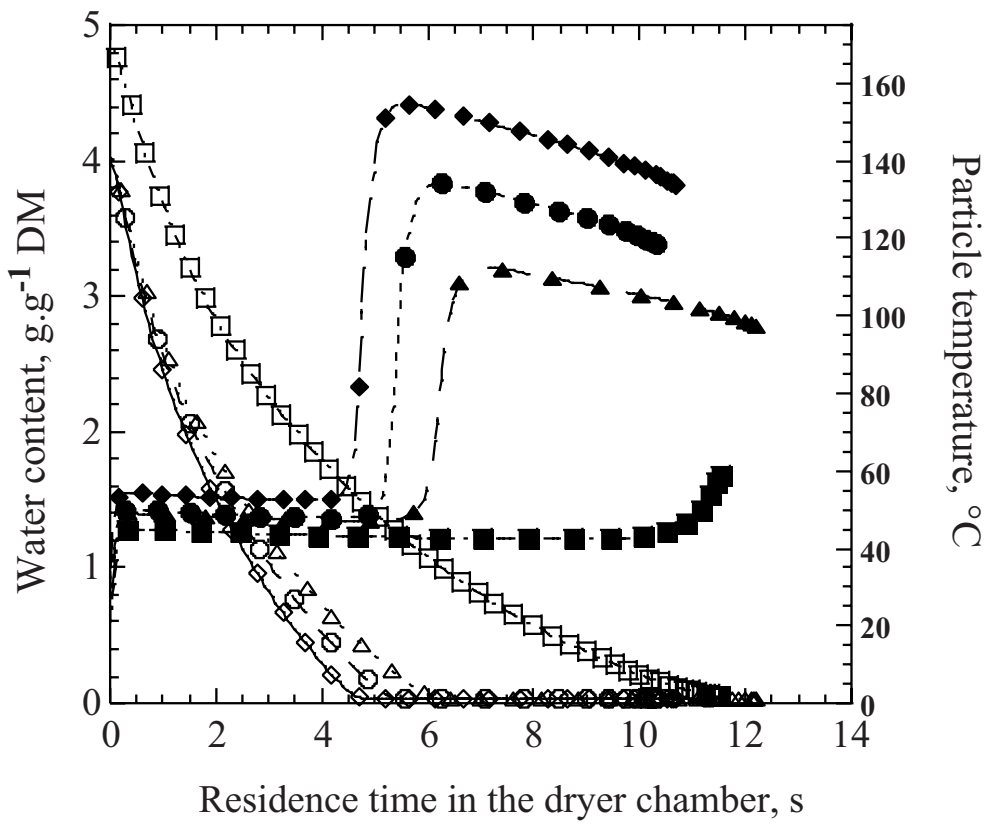

Figure 1. Hydro-thermal pathways of protein-rich droplets during their residence time in the dryer chamber, as predicted from a model based on mass- and energy-transfer balance equations applied to various air temperature conditions (see text). Water content (\% db): empty symbols; particle temperature $\left({ }^{\circ} \mathrm{C}\right)$ : full symbols; inlet-outlet air temperatures: square $\left(170 / 85^{\circ} \mathrm{C}\right)$; triangle $\left(217 / 107{ }^{\circ} \mathrm{C}\right)$; circle $\left(247 / 125^{\circ} \mathrm{C}\right)$; diamond $\left(260 / 138{ }^{\circ} \mathrm{C}\right)$.

Table II. Characteristics of exiting powders from the dryer chamber, depending on air inlet and outlet temperatures used for spray drying of whey protein solution (22\% dry matter).

\begin{tabular}{lcccc}
\hline Dried powders & $\mathrm{P} 170-85$ & $\mathrm{P} 217-107$ & $\mathrm{P} 247-125$ & $\mathrm{P} 260-138$ \\
\hline Outlet air temperature $\left({ }^{\circ} \mathrm{C}\right)$ & & & & \\
$\quad \mathrm{T}_{\mathrm{ao}}$ measured & 85 & 107 & 125 & 138 \\
$\quad \mathrm{~T}_{\mathrm{ao}}$ predicted & 72 & 96 & 124 & 132 \\
$\begin{array}{l}\text { Outlet product temperature }\left({ }^{\circ} \mathrm{C}\right) \\
\quad\end{array}$ & 59 & 97 & 125 & 134 \\
$\quad \mathrm{~T}_{\mathrm{po}}$ predicted & & & & \\
Outlet powder water content & 0.057 & 0.049 & 0.035 & 0.034 \\
$\quad \mathrm{~kg} \cdot \mathrm{kg}^{-1}$ measured & 0.049 & 0.035 & 0.034 & 0.034 \\
$\mathrm{~kg} \cdot \mathrm{kg}^{-1}$ predicted & & & & \\
Average median particle diameter & & & & \\
$\quad \mathrm{d}_{0.5}(\mu \mathrm{m})$ measured & $9.5 \pm 0.1^{\mathrm{a}}$ & $9.4 \pm 0.1^{\mathrm{a}}$ & $9.3 \pm 0.1^{\mathrm{a}}$ & $10.0 \pm 0.0^{\mathrm{a}}$ \\
Relative internal porosity, $\varepsilon(\%)$ & 27 & 32 & 40 & 45 \\
\hline
\end{tabular}

${ }^{\mathrm{a}} \pm$ are standard deviations. 
the physical modelling described in Section 2.1 led to the curves presented in Figure 1. The results in Table II indicate that increasing inlet air temperature from 170 to $260{ }^{\circ} \mathrm{C}$ was accompanied by an increase in the outlet air temperature (by $53^{\circ} \mathrm{C}$ ) and by a decrease in the product water content $(\sim 40 \%)$, in parallel with an increase in powder internal porosity $(\sim 30 \%)$ and a slight increase in average median particle diameter (from $9.5 \mu \mathrm{m}$ to $10.0 \mu \mathrm{m}$ ). Following the findings of Schuck et al. (this issue), the humidity of the outlet air may be used as a better indicator for powder characteristics than the temperature. Our results indicated that experimental and predicted data were fitted within less than the accepted 5\%, only for the higher air temperatures and water content predictions.

Images of spray-dried powders (Fig. 2) obtained by scanning electron microscope displayed a smooth surface and typical "skin-forming" behaviour resulting in hollow spheres and wall thickness, which appeared thinner for particles obtained at lower inlet air temperatures, as expected from the increased internal porosity values shown in Table II.

\subsection{Physico-chemical properties of rehydrated powders}

Other physico-chemical parameters of non-dried and dried protein samples are reported in Table III. They indicate that in $\mathrm{P} 247-125$ and $\mathrm{P} 260-138$ powders obtained at the highest air temperature conditions applied in this study, there was a greater decrease in the concentration of free lactose, in parallel with the development of HMF and a slight decrease (by approximately less than $10 \%$ relative to non-dried whey proteins) in protein solubility (Fig. 3). It is noteworthy to indicate that these results were also accompanied by changes in SDS-PAGE band patterns corresponding to $\alpha$-lactalbumin monomers $\left(14 \mathrm{~kg} \cdot \mathrm{mol}^{-1}\right)$ and high-molecular-weight covalentlybound aggregates $\left(>100 \mathrm{~kg} \cdot \mathrm{mol}^{-1}\right)$. It appeared that the increase in the loss of $\alpha$-lactalbumin monomers (by $\sim 20 \%$ for P247/125, instead of $\sim 70 \%$ for P260/138) and in the proportion of covalently-bound aggregates (by $\sim 50 \%$ for P247/125, instead of $\sim 70 \%$ for P260/138) was accompanied by a development of fluorescence compounds at $420 \mathrm{~nm}$ (not shown) and HMF (Tab. III). The latter results could be related to the loss of free lactose and creation of HMF [36], probably indicating the formation of early Maillard reaction products under the damaging conditions of high air temperature $[6,26,27]$.

Structural changes in whey proteins were also evaluated by differential scanning calorimetry (DSC) through determination of the energy $\left(\mathrm{Q}_{c a l}\right)$ involved in heat-induced transitions observed in protein solutions (22\% dry matter) before drying, and by dispersing the dried powders in water. Examples of DSC curves obtained by heating the non-dried solutions and re-hydrated powders from 10 to $100{ }^{\circ} \mathrm{C}$ at $10^{\circ} \mathrm{C} \cdot \mathrm{min}^{-1}$ are shown in Figure 4 . They had a similar shape, with a major peak transition located at around $80{ }^{\circ} \mathrm{C}$ and a minor one located at a lower temperature. The major peak corresponds to the denaturation of $\beta$-lactoglobulin (the major protein in our protein-rich product) and the minor peak to $\alpha$-lactalbumin denaturation. Peak temperatures and $\mathrm{Q}_{c a l}$ values determined from these DSC traces are reported in Table IV. It is shown that in comparison with the WP-L solution, $\mathrm{Q}_{\text {cal }}$ values, which can be used as an indicator index of protein conformational stability $[33,35,36]$, decreased by $\sim 30 \%$ for P170/85, P217/107 and P247/125, and by $\sim 50 \%$ for $\mathrm{P} 260 / 138$, obtained at the highest air temperature conditions.

Thus, it appears that protein structural changes evidenced by combined physico-chemical methods can take place 
(a)
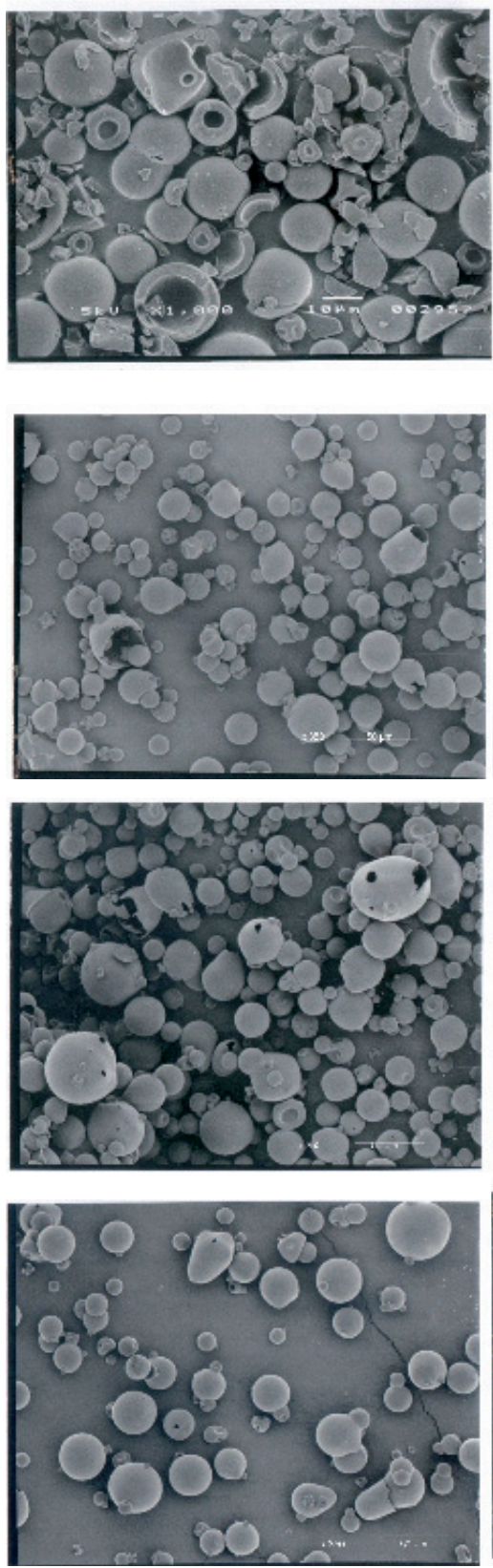

(b)

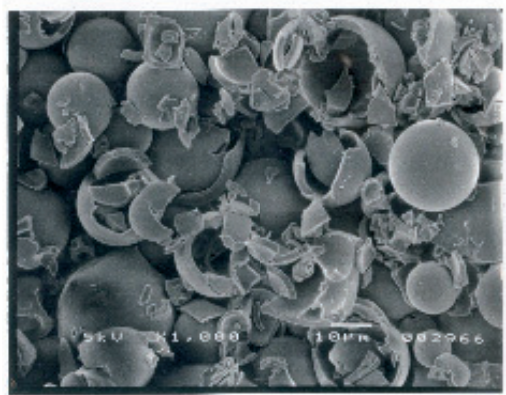

P138
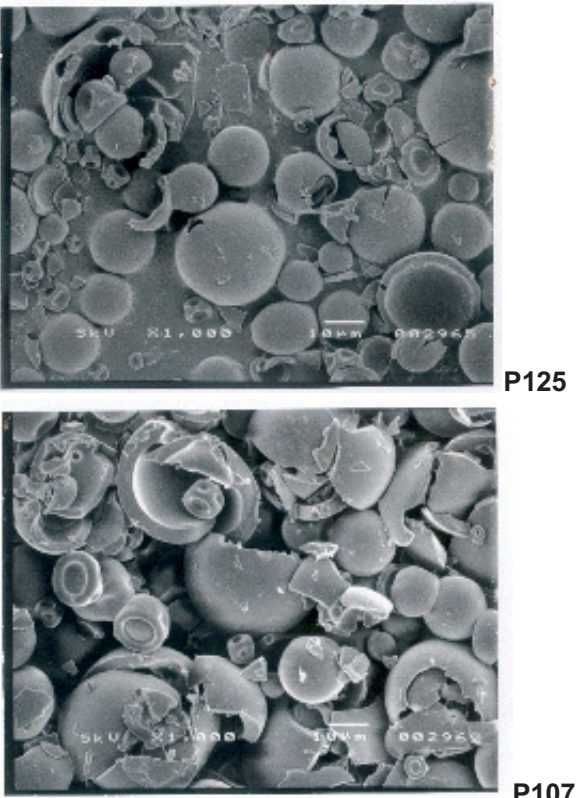

P107

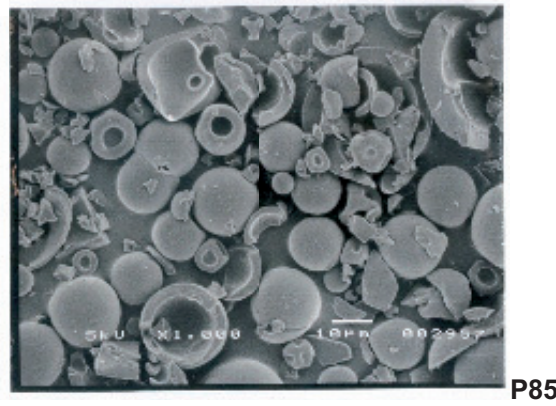

P85

Figure 2. Images obtained by scanning electron microscopy from powders before (a) and after grinding (b), obtained at $170 / 85^{\circ} \mathrm{C}, 217 / 107{ }^{\circ} \mathrm{C}, 247 / 125^{\circ} \mathrm{C}$ and $260 / 138{ }^{\circ} \mathrm{C}$ air inlet/outlet temperatures. 


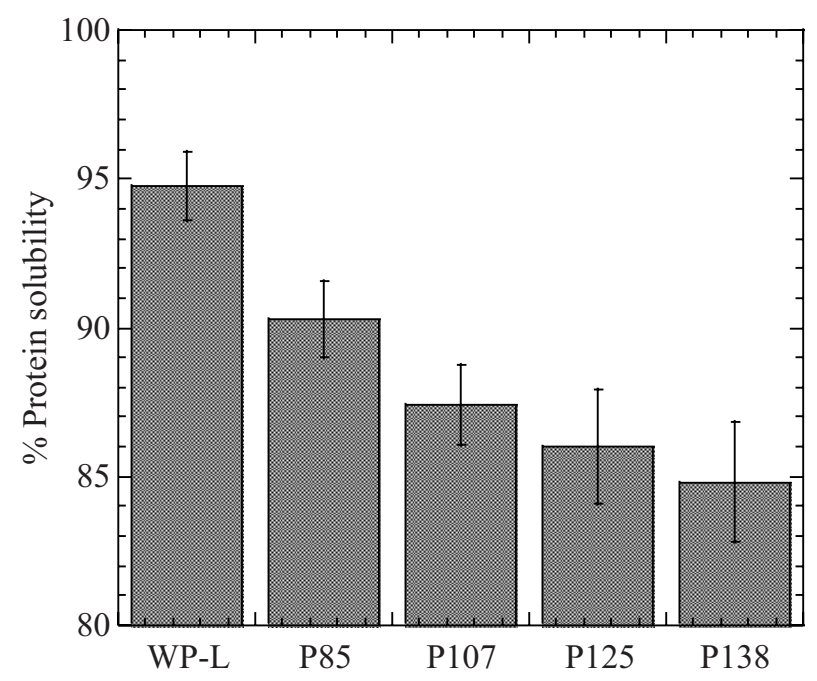

Figure 3. Protein solubility of non-dried whey protein-rich product, and re-hydrated exiting powders obtained at $170 / 85^{\circ} \mathrm{C}, 217 / 107{ }^{\circ} \mathrm{C}, 247 / 125^{\circ} \mathrm{C}$ and $260 / 138{ }^{\circ} \mathrm{C}$ air inlet/outlet temperatures.

Table III. Composition characteristics (\% wt) of non-dried whey protein-rich product (WP-L) and exiting powders obtained at various air temperature conditions ( \pm are standard deviations).

\begin{tabular}{lccccc}
\hline \multicolumn{1}{c}{ Protein sample (\%) } & WP-L & P170-85 & P217-107 & P247-125 & P260-138 \\
\hline Dry matter & $22.5 \pm 2.6$ & $94.2 \pm 1.6$ & $96.2 \pm 0.1$ & $96.8 \pm 0.5$ & $96.7 \pm 0.1$ \\
Ashes & $4.3 \pm 0.1$ & $4.1 \pm 0.1$ & $3.8 \pm 0.5$ & $3.9 \pm 0.5$ & $4.4 \pm 0.2$ \\
Lactose & $7.5 \pm 0.2$ & $7.4 \pm 0.2$ & $7.9 \pm 0.0$ & $7.0 \pm 0.0$ & $4.2 \pm 0.1$ \\
Hydroxymethylfurfural & ND & $10^{-4}$ & $10^{-4}$ & $2 \times 10^{-4}$ & $9 \times 10^{-4}$ \\
Protein & $84.9 \pm 1.8$ & $87.2 \pm 3.0$ & $86.6 \pm 4.5$ & $84.5 \pm 4.6$ & $82.4 \pm 2.0$ \\
$\quad$ & & & & \\
$\quad$ Protein composition & & & & & \\
Covalently-bound aggregates & $3.5 \pm 0.2$ & $4.5 \pm 0.5$ & $4.5 \pm 0.5$ & $7.9 \pm 1.4$ & $11.2 \pm 2.1$ \\
$\alpha$-lactoglobulin & $77.6 \pm 1.8$ & $74.0 \pm 1.2$ & $74.0 \pm 1.2$ & $74.0 \pm 1.2$ & $74.0 \pm 1.2$ \\
\hline & $18.9 \pm 1.9$ & $19.3 \pm 0.7$ & $19.3 \pm 0.7$ & $15.4 \pm 0.3$ & $13.4 \pm 0.6$ \\
\hline
\end{tabular}

in the dryer chamber. Different protein hydro-thermal pathways (Fig. 1) were accompanied by different structural changes, which were reflected by changes in protein solubility (Fig. 3), in the formation of covalently-bound aggregates and the appearance of HMF compounds (Tab. III), and also in the energy of heat-induced reactions as measured by
DSC (Tab. IV). Thus, spray drying of a whey protein-rich product (18.5 wt $\%$ protein concentration and $\mathrm{pH}$ 6.7) leads to different levels of heat-induced denaturation-aggregation depending on the particle hydro-thermal path in the dryer chamber. The increased structural changes observed when particle temperatures in the drying chamber (Fig. 1) were far above 


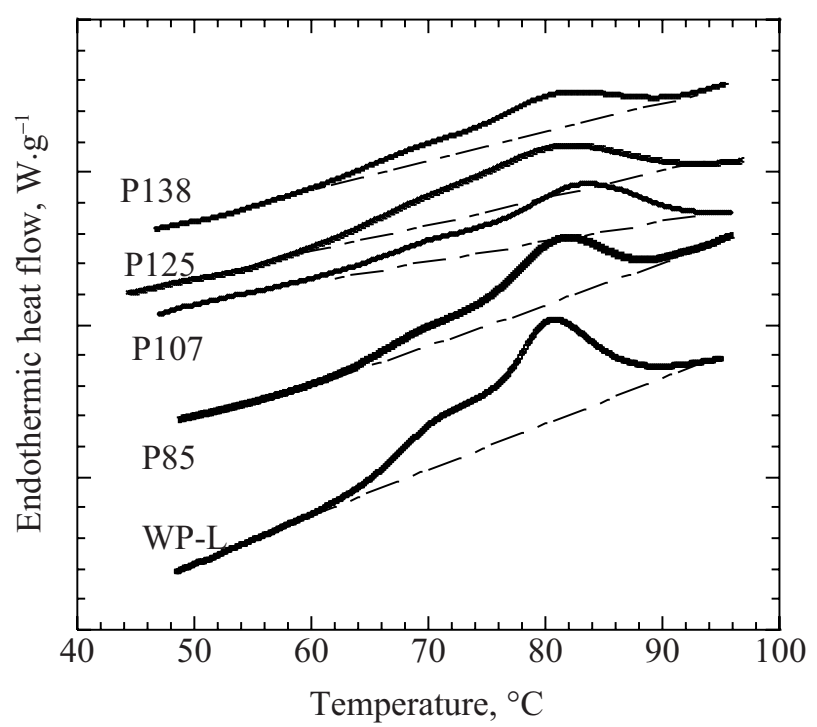

Figure 4. DSC heating curves obtained from non-dried whey protein solutions (WP-L) and from dispersions of spray-dried powders obtained at $170 / 85^{\circ} \mathrm{C}, 217 / 107^{\circ} \mathrm{C}, 247 / 125^{\circ} \mathrm{C}$ and $260 / 138{ }^{\circ} \mathrm{C}$ air inlet/outlet temperatures.

Table IV. Comparison between calorimetric parameters obtained from non-dried whey protein solution (WP-L) and the various re-hydrated powders (P170-85, P217-107, P247-125 and $\mathrm{P} 260-138$ ) obtained at different air temperature conditions. $\mathrm{T}_{\text {shoulder }}$ and $\mathrm{T}_{\max }$ are the temperatures corresponding to $\alpha$-lactalbumin and $\beta$ lactoglobulin denaturation, and $\mathrm{Q}_{c a l}$ is the apparent total heat of reaction.

\begin{tabular}{cccc}
\hline & $\begin{array}{c}\mathrm{T}_{\text {shoulder }} \\
{ }^{\circ} \mathrm{C}\end{array}$ & $\begin{array}{c}\mathrm{T}_{\max } \\
{ }^{\circ} \mathrm{C}\end{array}$ & $\begin{array}{c}\mathrm{Q}_{\text {cal }} \\
{\mathrm{J} \cdot \mathrm{g}^{-1}}\end{array}$ \\
\hline WP-L & 70.5 & 79.3 & 13 \\
$\mathrm{P} 170-85$ & 70.0 & 81.0 & 9.2 \\
$\mathrm{P} 217-107$ & 70.2 & 82.5 & 8.8 \\
$\mathrm{P} 247-125$ & 69.5 & 82.6 & 8.1 \\
$\mathrm{P} 260-138$ & 68.5 & 83.0 & 6.5 \\
\hline
\end{tabular}

the wet bulb temperature $\left(<60{ }^{\circ} \mathrm{C}\right)$ could explain the fact that powders that left the dryer at $132{ }^{\circ} \mathrm{C}$ were more affected in their conformational state than powders exiting at $125{ }^{\circ} \mathrm{C}$ and much more than powders exiting at $107{ }^{\circ} \mathrm{C}$ and at $85^{\circ} \mathrm{C}$, the latter being in the least denatured states.

\subsection{Effects of air drying conditions on protein foaming properties}

Whey proteins are used in the food industry as functional ingredients, combining not only high nutritional quality, but also aggregation, emulsifying and foaming properties. Concerning foaming ingredients, their ability to effectively generate foam is necessary, but their foam stabilisation effects against liquid drainage, gas bubbles' collapse or disproportionation (interbubble gas diffusion) are the most important criteria for their usefulness in aerated food formulations. In previous studies we showed that application of mild heat-treatments to globular protein solutions before foaming led to differences in foam structure compared with the nontreated protein solutions $[18,19,23,34$, 35]. Particularly, we showed recently that protein solutions obtained from P170-85 and $\mathrm{P} 260-138$ powders' rehydration behave differently in regards to structural 


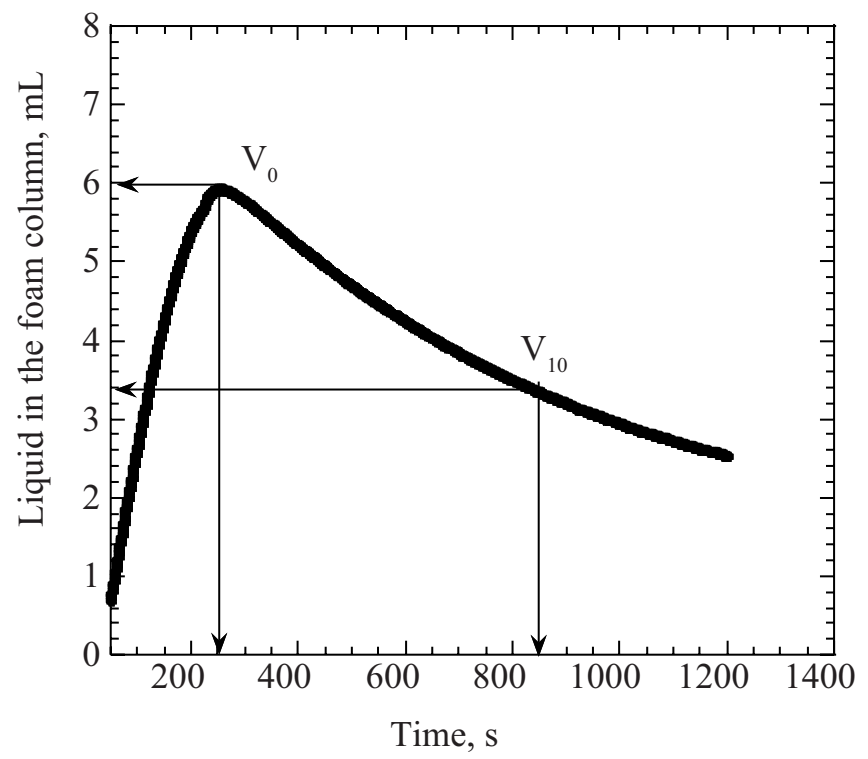

Figure 5. Time evolution of liquid volume in an example of column foam containing a whey protein sample, as measured by conductimetry, for $20 \mathrm{~min}$ after the end of air sparging. $\mathrm{V}_{0}$ is the maximum liquid volume incorporated at the end of air sparging, $\mathrm{V}_{10}$ is the liquid volume retained in the column foam $10 \mathrm{~min}$ after the end of air sparging.

changes and foaming properties, compared with the non-dried protein solution.

In the present study, application of the same methodology to protein powders produced by using intermediate inlet air temperatures $\left(217{ }^{\circ} \mathrm{C}\right.$ and $\left.247{ }^{\circ} \mathrm{C}\right)$ seemed to confirm the trends reported for both the powder characteristics and physicochemical properties of protein solutions obtained by dispersing powders in water. Probably, in the previous study [34], the foam was formed by air sparging in the non-dried whey protein solutions or in P217 and P247 re-hydrated powders, containing $0.5 \mathrm{wt} \%$ proteins in $0.5 \%$ $\mathrm{NaCl}$. Global foam stability, against liquid drainage after the end of air sparging, was monitored by conductimetric measurements, as described in [35]. The curve in Figure 5 shows an example of the change in liquid retained in the foam during the sparging period, and during the draining ( 20 min) following the sparging. In our experimental conditions, we observed that all the protein solutions required about the same bubbling time ( $3 \mathrm{~min})$ to attain the maximum foam height corresponding to a $52-\mathrm{mL}$ foam column, and slight differences in the total amount of liquid $\left(\mathrm{V}_{0}\right)$ incorporated (during the sparging period). Foam density values $\left(D_{0}\right)$ reached at the end of air sparging, as evaluated from the maximum liquid volume $\left(\mathrm{V}_{0}\right)$ and air, were slightly higher for P260-138 ( 119 g. $\left.\mathrm{L}^{-1}\right)$ than for the other powders obtained at lower air temperatures $\left(\sim 105 \mathrm{~g} \cdot \mathrm{L}^{-1}\right)$. As foam density in bubbling tests is inversely correlated to foam expansion in whipping tests $[17,19$, $30,42]$, it appeared that spray drying at the highest air temperature conditions enhanced the protein foamability. This slight difference in foamability between the protein solution obtained by re-hydration of 

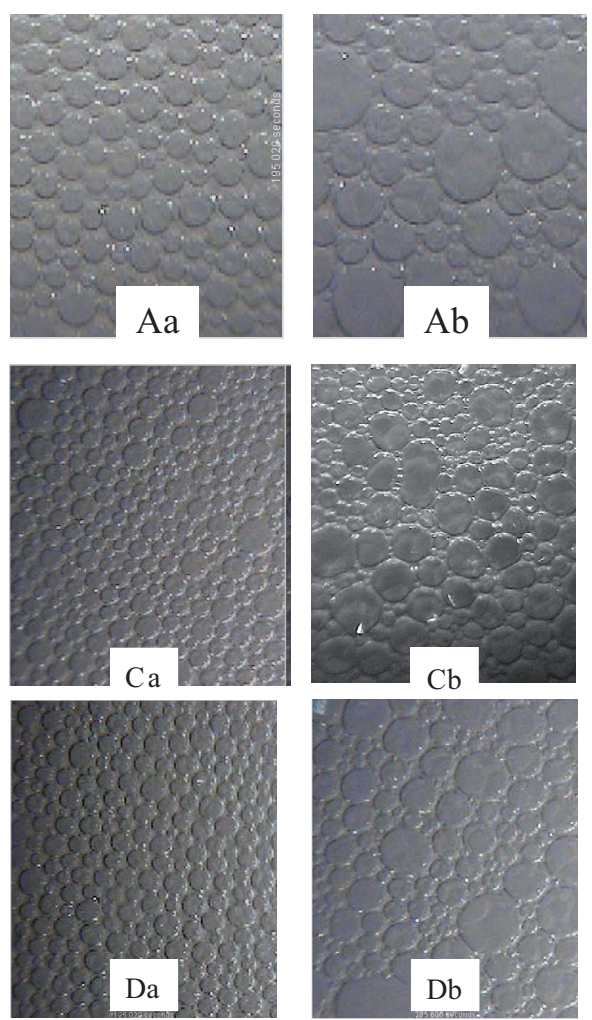
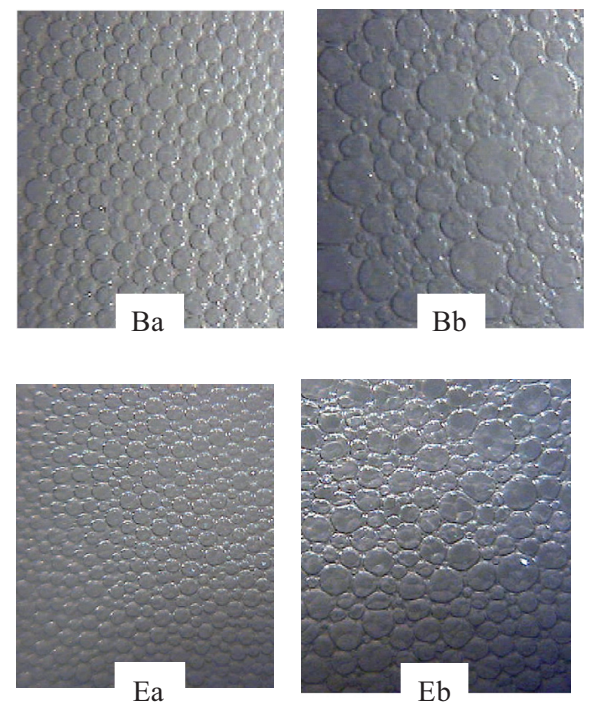

Figure 6. Cropped images taken at the end (a) and $10 \mathrm{~min}$ (b) after the end of air sparging into whey protein solutions before spray drying (A), whey protein solutions obtained by re-hydration of various powders obtained at $170 / 85^{\circ} \mathrm{C}$ (B), $217 / 107^{\circ} \mathrm{C}$ (C), $247 / 125^{\circ} \mathrm{C}$ (D) and $260 / 138^{\circ} \mathrm{C}$ (E) air inlet/outlet temperatures.

P260-138 powder, and those obtained from non-dried protein solution and the other powders was reflected in the appearance of air bubbles, which were acquired just after the end of air sparging (Fig. 6). The air bubbles in Figure 6 Ea showed slightly more and smaller bubbles than in the other images. Variation in foam stability based on the proportion of residual liquid, $10 \mathrm{~min}$ after the end of sparging (Fig. 7), indicated that foams obtained from spray-dried proteins in our conditions retained a higher proportion of liquid, particularly for protein P260-138. Images of air bubbles (Fig. 6B) acquired 10 min after the end of sparging show less numerous and larger bubbles than just after the end of sparging. The appearance of larger air bubbles at the expense of small bubbles could be due to coalescence (breaking up of adsorbed protein films around adjacent bubbles) or disproportionation (shrinking and disappearance of small bubbles due to air pressure differences between small and large bubbles). Visual observation of the images shown in Figure 6, and trends of liquid drainage deduced from simultaneous conductimetric measurements, indicated clearly that of all the foams obtained from the different protein solutions, the foam obtained from P260-138 powder gave the highest foamability (larger 


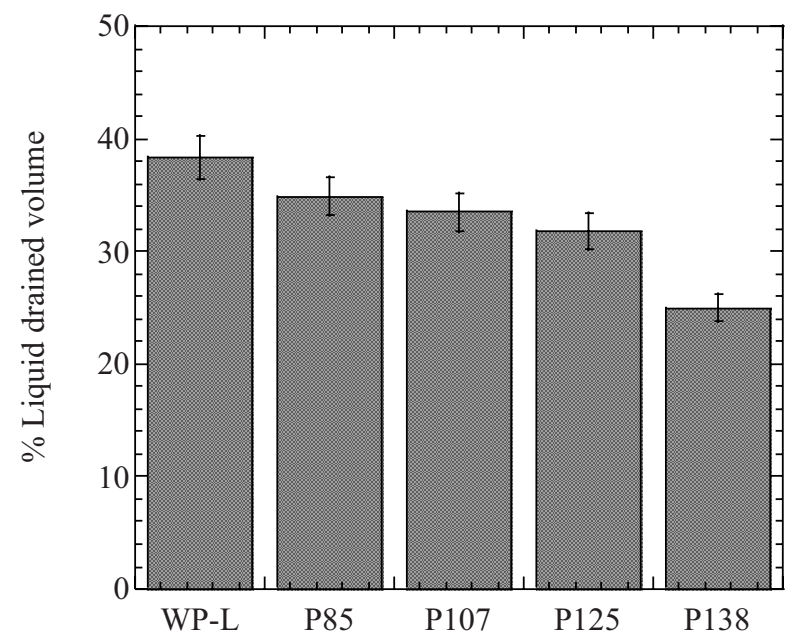

Figure 7. Percentage of liquid volume retained in the various column foams containing whey protein solutions before spray drying (WP-L), whey protein solutions obtained by re-hydration of various powders obtained at $170 / 85^{\circ} \mathrm{C}, 217 / 107{ }^{\circ} \mathrm{C}, 247 / 125{ }^{\circ} \mathrm{C}$ and $260 / 138{ }^{\circ} \mathrm{C}$ air inlet/outlet temperatures, respectively.

number of smaller bubbles just after air sparging) and highest foam stability against liquid drainage, as reflected in a larger number of small residual air bubbles, 10 min after the end of air sparging.

Previously we showed that preheating of whey protein-rich solutions before emulsification $[33,39]$ or before foaming $[19,23,35]$ could help to increase the ability of proteins to provide structure and stability for dispersed food systems. As in our very recent studies [3,34], we confirm that controlling spray-drying operating conditions could provide proteinrich powders with different structural behaviours and foaming properties. To be a good foaming agent, protein molecules must be able to adsorb from bulk medium to the air-liquid interface and to entrap the gas bubbles in a continuous liquid lamellar phase. To be a good foam stabiliser, the adsorbed proteins must be able to prevent reduction of liquid lamella thickness, the close approach of small and large sized bubbles leading to reduction in liquid drainage $[14,15,18,40]$. Thus, spray drying in a co-current configuration of whey protein-rich products, in controlled operational conditions, could be proposed as a new technological way to enhance structure-forming properties in proteinstabilised foams, without additional processing equipments or steps.

Acknowledgements: C. Bernard is grateful to the École Doctorale ABIES for financial support (Ph.D. grant). The authors acknowledge T. Meylheuc (INRA-Massy) for his helpful support for MEB observations, and P. Schuck (INRA-Rennes/STLO) and J.F. Boudier (Ingredia-France) for fruitful discussions.

\section{REFERENCES}

[1] Anandharamakrishnan C., Rielly C.D., Stapley A.G.F., Thermal denaturation of whey proteins during spray-drying, in: Proceedings of the 15th International Drying Symposium, Budapest, Hungary (2006) 1265-1272.

[2] Andrieu J., Stamatopoulos A., Zafiropoulos M., Equation for fitting desorption isotherms 
of durum wheat pasta, J. Food Technol. 40 (1985) 651-657.

[3] Bernard C., Broyart B., Vasseur J., Relkin P., Production of whey protein powders with controlled end-use properties, in: Proceedings of the 15th International Drying Symposium, Budapest, Hungary (2006) 1279-1286.

[4] Birchal V.S., Passos M.L., Modelling and simulation of drying milk emulsion in spray dryers, in: Proceedings of the 14th International Drying Symposium, Sao Paulo, Brazil (2004) 1561-1568.

[5] Birchal V.S., Passos M.L., Wildhagen G.R.S., Mujumdar A.S., The influence of spray dryer operation variables on milk powder quality, in: Proceedings of the 14th International Drying Symposium, Sao Paulo, Brazil (2004) 389-396.

[6] Birlouez-Aragon I., Sabat P., Gouti N., A new method for descrimining milk heat treatment, Int. Dairy J. 12 (2002) 59-67.

[7] Borios C., Lancelot J., Davenas P., Ilari J.L., Vérification industrielle de l'influence de certains paramètres technologiques de fabrication sur les propriétés physiques de la poudre de lait écrémé, Ind. Alim. Agricol. 101 (1984) 1211-1219.

[8] Chong L.V., Chen X.D., A mathematical model of the self-heating of spray-dried food powders containing fat, protein, sugar and moisture, Chem. Eng. Sci. 54 (1999) 41654178.

[9] Damodaran S., Protein-stabilized foams and emulsions, M. Dekker Inc., New York, USA, 1997, pp. 57-110.

[10] Donovan M., Mulvihill D.M., Thermal denaturation and aggregation of whey proteins, Irish J. Food Sci. Technol. 11 (1987) 1187100.

[11] Farid M., A new approach to modelling of single droplet drying, Chem. Eng. Sci. 58 (2003) 2985-2993.

[12] Ferrari G., Meerdink G., Walstra P., Drying kinetics for a single droplet of skim-milk. J. Food Eng. 10 (1989) 215-230.

[13] Fletcher D.F., Guo B., Harvie D.J.E., Langrish T.A.G., Nijdam J.J., Williams J., What is important in the simulation of spray dryer performance and how do current CFD models perform? Appl. Math. Modell. 30 (2006) 1281-1292.

[14] Galani D., Apenten R.K.O., Heatinduced denaturation and aggregation of $\beta$-lactoglobulin: kinetics of formation of hydrophobic and disulphide-linked aggregates, Int. J. Food Sci. Technol. 34 (1999) 467-476.

[15] German J.B., O’Neil T.E., Kinsella J.E., Film forming and foaming behaviour of food proteins, J. Am. Oil Chem. Soc. 62 (1985) 1358-1366.

[16] Graham D.E., Phillips M.C., The conformation of proteins at the air-water interface and their role in stabilizing foams, in: Ackers R.J. (Ed.), Foams, Academic Press, London, England, 1976, pp. 195-215.

[17] Guillerme C., Loisel W., Bertrand D., Popineau Y., Study of foam stability by video image analysis: relationship with the quantity of liquid in foams, J. Text. Stud. 24 (1993) 287-303.

[18] Hagolle N., Launay B., Relkin P., Impact of structural changes and aggregation on adsorption kinetics of ovalbumin at acid and neutral pH, Colloids Surf. B: Biointerfaces 10 (1998) 191-198.

[19] Hagolle N., Relkin P., Popineau Y., Bertrand D., Study of the stability of egg white protein-based foams: effect of heating protein solution, J. Sci. Food Agric. 80 (2000) 1245-1252.

[20] Langrish T.A.G., Fletcher D.F., Spray drying of food ingredients and applications of CFD in spray drying, Chem. Eng. Process 40 (2001) 345-354.

[21] Lin S.X.Q., Chen X.D., The reaction engineering approach to modelling the cream and whey protein concentrate droplet drying, Chem. Eng. Process. 46 (2007) 437-443.

[22] Loncin M., Bimbenet J.J., Bases du génie des procédés alimentaires, Masson (Ed.), Paris, 1995.

[23] Marin I., Relkin P., Foaming properties of $\beta$ lactoglobulin: impact of pre-heating and addition of isoamyl acetate, Int. J. Food Sci. Technol. 34 (1999) 515-522.

[24] Masters K., Spray Drying in: practice, SprayDryConsult International Aps (Ed.), Denmark, The Netherlands, 2002.

[25] Millqvist-Fureby A., Elofsson U., Bergenstähl B., Surface composition of spray-dried milk protein-stabilized emulsions in relation to pre-heat treatment of proteins, Colloids Surf. B: Biointerfaces 21 (2001) 47-58.

[26] Morales F.J., Romero C, Jimenez-Perez S., Fluorescence associated with Maillard 
reaction in milk and milk-resembling systems, Food Chem. 57 (1996) 423-428.

[27] Morr C., Ha E.Y.W., Whey protein concentrates and isolates: processing and functional properties, Food Sci. Nutr. 33 (1993) 431476.

[28] Nijdam J.J., Langrish T.A.G., The effect of surface composition on the functional properties of milk powders, J. Food Eng. 77 (2006) 919-929.

[29] Oldfield D.J., Taylor M.W., Singh H., Effect of preheating and other process parameters on whey protein reactions during skim milk powder manufacture, Int. Dairy J. 15 (2005) 501-511.

[30] Patel P.D., Stripp A.M., Fry J.C., Whipping test for the determination of foaming capacity of protein: A collaborative study, Int. J. Food Sci. Technol. 33 (1988) 57-63.

[31] Parti M., Palancz B., Mathematical model for spray drying, Chem. Eng. Sci. 29 (1974) 355-362.

[32] Pisecky J., Spray drying in the cheese industry, Int. Dairy J. 15 (2005) 531-536.

[33] Relkin P., Using DSC for monitoring protein conformation stability and effect of fat droplets crystallinity in complex food emulsions, in: Lôrincz D. (Ed.), The nature of biological systems as revealed by thermal analysis, Kluwer Academic Publishers, London, England, 2004, pp. 99-126.

[34] Relkin P., Bernard C., Meylheuc T., Vasseur J., Courtois F., Production of whey protein aggregates with controlled end-use properties, Lait 87 (2007) 337-348.
[35] Relkin P., Hagolle N., Dalgleish D.G., Launay B., Foam formation and stabilisation by pre-denatured ovalbumin, Colloids Surf. B: Biointerfaces 12 (1999) 409-416.

[36] Relkin P., Launay B., Concentration effects on the kinetics of $\beta$-lactoglobulin heat denaturation: a differential scanning calorimetric study, Food Hydrocoll. 4 (1990) 19-32.

[37] Schuck P., Piot M., Méjean S., Fauquant J., Brulé G., Maubois J.-L., Déshydratation par atomisation de phosphocaséinate natif obtenu par microfiltration sur membrane, Lait 74 (1994) 375-388.

[38] Singh H., Creamer L.K., Denaturation, aggregation and heat stability of milk protein during the manufacture of skim powder, J. Dairy Res. 58 (1991) 269-283.

[39] Sourdet S., Relkin P., César B., Structuration of complex food emulsions by preheated milk proteins, Colloids Surf. B: Biointerfaces 31 (2003) 55-64.

[40] Straatsma J., Van Houwelingen G., Steenbergen A.E., De Jong P., Spray drying of food products: 1. Simulation model, J. Food Eng. 42 (1999) 67-72.

[41] Verdurmen R.E.M., Straatsma H., Verschueren M., Van Haren J.J., Smit E., Bargeman G., De Jong P., Modelling spray drying processes for dairy products, Lait 82 (2002) 453-463.

[42] Wilde P.J., Clark D.C., Foam formation and stability, in: Hall G.M. (Ed.), Methods of testing protein functionality, Blackie Academic and Professional, London, England, 1996, pp. 110-152. 